\title{
Study of physicochemical and hematological effects of Bheema river water on Albino rat (Rattus norvegicus)
}

\author{
Tathagat. E. Waghmare ${ }^{1}$ and Ramesh. L. Londonkar* \\ Department of Biotechnology Gulbarga University Gulbarga, Karnataka-585106, India \\ Email.tathagat.waghmare@yahoo.com \\ londonkarramesh53@gmail.com*
}

\begin{abstract}
The present study was designed to investigate the quality of Bheema river water on its potability and haematological parameters on albino rats. The rats were divided into four groups and were fed with Bheema river water subsequently for one day, four day and seven day. The rats of control group received only normal tap water, where as group one, group two, and group three were fed with Bheema river water for one day four day and seven day. The rats treated for two days have shown significant reduction in the Hemoglobin content and, differential counts compared to other group. Simultaneously we have checked the various physical and chemical parameters of Bheema river water where we observed significant variations in the chemical analysis of the water quality compare to normal water which shows that the Bheema river water is polluted and not good for drinking purpose.
\end{abstract}

Key words: Bheema River water, Haematological, Physicochemical parameters, Rattus norvegicus, Water parameters.

\section{Introduction}

Water is the prime constituent that supports human life. Reservoirs form unique biological freshwater ecosystem on the planet earth. Water also known as blue gold, and is one of the most precious natural resources and responsible for life on Earth, the evolution of life and development of human civilization could not have been possible without water. All great civilizations of the world therefore are evolved around rivers. Rapidly increasing population, indiscriminate urbanization and unplanned industrialization along the rivers as well as in the catchment areas have put tremendous stress on water resources and their quality. Indiscriminate discharge of industrial effluent in rivers has been a common phenomenon leading to sever depletion of water quality and aquatic life.

Bheema River is a major river in south India it flows from south east covering $861 \mathrm{~km}$ through Maharashtra, Karnataka and Andhra Pradesh states before entering the Krishna River. Bheema River originates near Bheemashankar temple in the Bheemashankar hills in Ambegaon taluka on the western side of the Western Ghats known as sahyadri in Pune district of Maharashtra. It merges into the Krishna along the border between Karnataka and Andhra Pradesh about $25 \mathrm{~km}$ North of Raichur District. The proposed study area i.e. Bheema river near Saradagi dam is located nearly about $25 \mathrm{~km}$ away from the Gulbarga city. It is the main water source for drinking to the Gulbarga District, hence the evaluation of the Bheema river water is necessary to assess its quality potability as well as to find out source of pollution, which ultimately helps in planning the water quality management. Such studies helps to find out whether water is suitable for drinking purpose or for specific industrial purpose, and if not, to choose the most effective treatment strategy; to determine the extent of pollution and to suggest a possible remedy; to determine the efficiency towards natural purification when sewage and industrial wastes are discharged into water courses; and to ascertain the effect of rainfall on water quality. Primary assessment of water pollution level in the natural environment is of great concern to the Scientists, Environmentalists and Engineers as it also help in assessing adverse effects water bodies on human beings and environment.

Blood is the fluid of life, responsible in transporting oxygen from the lungs to body tissue and drives carbon dioxide from body tissue to the lungs. Blood also helps in transport of nourishment from the place of digestion and hormones from glands throughout the body. It is considered as fluid of health, which carries disease fighting substances to the tissue and waste to the kidneys. Because it contains living cells, the blood is alive. Red blood cells and white blood cells are responsible for nourishing and cleansing the body. Since the cells are alive, they too need nourishment.

Vitamins and Minerals keep the blood healthy. The blood cells have a definite life cycle, just as all living organisms do. Approximately 55 percent of blood is plasma, a straw-colored clear liquid. The liquid plasma carries the solid cells and the platelets which help in blood clot. Without blood platelets, if there is an accidental wound it would bleed to death. 
After consumption of polluted water, the water pollutants will be, absorbed through the intestines, they can enter the blood stream, where their potential harmful effects are distributed throughout the body. Blood passes through all the body's organs and tissues, and can carry toxic substances as well as beneficial substances, such as oxygen, to cell and removes toxoides from the cell.

Some water pollutants interfere with the function of blood, which results in detrimental effects on all organs of the body. For example, hemoglobin is the part of the red blood cell that carries oxygen from the lungs to the tissues of the body. Carbon monoxide, a product of incomplete combustion, binds over 200 times more firmly to hemoglobin than oxygen, seriously interfering with blood's oxygen-transport capability. Severe acute exposure can result in death due to asphyxiation or cause permanent damage to the central nervous system.

\section{Materials and Methods}

The study was carried out to investigate the various physico-chemical properties of Bhīma river water and its Haematological effect on albino rat. The water sample was obtained from the Bheema River, situated nearer to the Saradagi dam in Gulbarga District. observations of various physical and chemical parameters like PH, Temperature, Odor, Color, Determination of TDS, Fluoride, Iron, Sulphate, Acidity, Nitrate, Phosphate, Dissolved Organic matter, Dissolved Oxygen,(DO), BOD, Alkalinity, Calcium, Chloride, Hardness etc is measured as per standard methods.

Inbred Healthy, adult albino rats Rattus norvegicus weighing between 200to 250 gm were used for experiments. They were housed in an air-cooled animal house at a temperature of $260 \pm 20 \mathrm{C}$ and exposed to $12 \mathrm{~h}$ of daylight. The animals were divided into four different groups containing six rats in each group. Group Iserved as control received only tap water. Group II, III, and IV were treated with Bhīma river water obtained from saradagi dam, respectively for 1, 4 and 7 days.

The animals were maintained on standard diet (Hindustan lever ltd.). After completing treatment feeding days the animals were anesthetized in the closed anesthetic jar containing anesthetic chemical called Diethyl ether, and blood was extracted through retro orbital puncture. The liver, kidney, heart and adrenal gland were carefully dissected out separated from fatty tissues and blotted free of blood, weighed for the weight variation in electronic balance respectively. The total erythrocytes and total leucocytes count method was done according to the method described by (Wintrobe,1930); percentage of hemoglobin is calculated as per the method described by (Crossby et al., 1954) and haematocrit values were studied in blood as per the method of Strumia et al., 1954.

\section{Results and discussion}

III.1 Analysis of Various water parameters of water sample obtained from Bheema River.

Table No. 1.

\begin{tabular}{|c|c|c|c|c|}
\hline \multirow{2}{*}{$\begin{array}{l}\text { Sl. } \\
\text { No }\end{array}$} & \multirow[t]{2}{*}{ Water Parameters } & \multirow[t]{2}{*}{ Bheema River Water Sample } & \multicolumn{2}{|c|}{ Standard Value } \\
\hline & & & WHO & BIS \\
\hline 1. & Ph & 10 & $6.5-8.5$ & $6.5-8.5$ \\
\hline 2. & Temperature $[-]$ & 22.5 & 46.1 & 56.2 \\
\hline 3. & Fluoride & 0.6 & $1.5 \mathrm{mg} / \mathrm{L}$ & $1.5 \mathrm{mg} / \mathrm{L}$ \\
\hline 4. & Total Dissolved Solids [TDS] & $3000 \mathrm{Mg} / \mathrm{Litr}$ & $1000 \mathrm{mg} / \mathrm{Lit}$ & $1000 \mathrm{mg}$ Lif \\
\hline 5. & Iron & $1 \mathrm{Mg}$ Lit & $1 \mathrm{Mg}$ Lit & $1 \mathrm{Mg} / \mathrm{Lit}$ \\
\hline 6. & Sulphate $\left[\mathrm{SO}_{4}\right]$ & $480 \mathrm{mg} / \mathrm{Lit}$ & $400 \mathrm{Mg} / \mathrm{Lit}$ & $400 \mathrm{Mg} / \mathrm{Lit}$ \\
\hline 7. & Acidity & 82 & $\ldots$ & $\ldots$ \\
\hline 8. & Nitrate $\left[\mathrm{NO}_{3}\right]$ & $5 \mathrm{Mg} / \mathrm{Lit}$ & $100 \mathrm{Mg} / \mathrm{Lit}$ & $100 \mathrm{Mg} / \mathrm{Lit}$ \\
\hline 9. & Phosphate $\left[\mathrm{PO}_{4}\right]$ & $0.25 \mathrm{Mg} / \mathrm{Lit}$ & $0.01 \mathrm{Mg} / \mathrm{Lit}$ & $\cdots$ \\
\hline 10. & Dissolved Oxygen [DO] & $0.6 \mathrm{Mg} / \mathrm{Lit}$ & $5.00 \mathrm{Mg} / \mathrm{Lit}$ & $\cdots$ \\
\hline 11. & BOD & 0.008 & $\operatorname{lmg} / \mathrm{Lit}$ & $\ldots$ \\
\hline 12. & Calcium $[\mathrm{Ca}]$ & $19.23 \mathrm{Mg} \mathrm{Lit}$ & $75-200 \mathrm{mgL}$ & $75 \mathrm{Mg} / \mathrm{Lit}$ \\
\hline 13. & Chloride $\left[\mathrm{Cl}_{2}\right]$ & $126.22 \mathrm{mg} / \mathrm{Lit}$ & $250 \mathrm{Mg} / \mathrm{L}$ & $250 \mathrm{Mg} / \mathrm{L}$ \\
\hline 14. & Hardness & $105 \mathrm{Mg} / \mathrm{Lit}$ & $500 \mathrm{Mg} / \mathrm{L}$ & $300 \mathrm{Mg} / \mathrm{L}$ \\
\hline
\end{tabular}




\section{III.1.1. Effect on Physico-Chemical parameters of Bheema River water.}

The data (Table No.1) reveals that the $\mathrm{pH}$ value of Bheema River water collected at saradagi dam was found to be 10 which is above the normal range this causes Gastrointestinal irritation. Temperature of the Bhīma river water was recorded as $22.5^{\circ} \mathrm{C}$, according to WHO and BIS the normal temperature of river water should be 46.1-56. $2^{\circ} \mathrm{C}$ (Table.1). The decrease in the water temperature of the river affects the metabolic activities of the aquatic life and the temperature is one of the most important factor in aquatic environment (Singh et al-2005). It also affects solubility of oxygen in water (Ranjitha Chaudhari e al-2013). Solubility of oxygen water increases with decrease in temperature (Joshi et al.2001). As the amount of oxygen that can be dissolved in water is partly governed by temperature. Temperature also influences the rate of Photosynthesis. In the present study decrease in temperature has affected aquatic life. The fluoride content of water was found to be $0.6 \mathrm{mg} / \mathrm{lit}$ which is less than the permissible range of potable water as per WHO and BIS, this lower fluoride may results in the demineralization of the tooth enamels. The values of Total Dissolved Solids (TDS) in Bheema river was found to be higher than the permissible limit which make the water unsafe for drinking purpose. Water containing total dissolved solids (TDS) concentration below $1000 \mathrm{mg} / \mathrm{l}$ is usually acceptable to consumers. Although acceptability may vary according to circumstances (WHO Guidelines for drinking water quality).

In the Normal river water the concentration of Iron content should be $0.5-10.0 \mathrm{mg} / \mathrm{lit}$, where as concentration of iron in Bheema river water was found to be $1 \mathrm{ppm}$ which is equal to $1 \mathrm{mg} / \mathrm{lit}$, hence the iron content in Bheema river water found to be within permissible limit. Even there is a huge alteration in the sulfate value which was found to be non permissible range, it is ecologically important for the growth of the plants, its deficiency in water bodies may inhibit the development of planktons. Excess sodium sulfate should not be present in drinking water as they cause cathartic action. Uncontrolled observation of sulfate in drinking water at higher concentration $(500-700 \mathrm{mg} / \mathrm{lit})$ cause diarrhea (Peterson. NL: Sulfate in drinking water; official bulletin ND water sewage works 18:6-11, 1951). Nitrates are forms of element Nitrogen which makes up about $80 \%$ of air we breathe. As an essential compound of life, nitrogen is recycled continuously by plants, animals and is found in the cells of all living things. In the present study Nitrate content of Bheema River water was found to be $5 \mathrm{mg} / \mathrm{l}$ which is less than the permissible limit prescribed by the BIS standards $100 \mathrm{mg} / \mathrm{l}$. (Table-1). Hence there is death of fishes observed, it may be due to low level availability of minerals. Phosphate concentration comes from fertilizers, pesticides, industry and cleaning compounds.

The amount of phosphate content in the Bheema River was found to be $0.025 \mathrm{mg} / \mathrm{lit}$ which accelerates the eutrophication process in the lakes. Hence the water is not well fit for the domestic use. Dissolved Oxygen is necessary for good water quality. Oxygen is a necessary element to all forms of life. Natural stream purification processes require adequate oxygen levels in order to provide for aerobic life forms. As dissolved oxygen levels in Bheema River water drop below $5.0 \mathrm{mg} / \mathrm{l}$, which puts the aquatic life under stress. It is well established that as there is lower the $\mathrm{O}_{2}$ concentration, the greater the stress. Oxygen levels that remain below 1-2 mg/l in Bheema water for a few hours can result in large fish death; The Dissolved oxygen content in the Bheema River (Saradagi Dam) was found to be $0.6 \mathrm{mg} / \mathrm{lit}$ as this is below the acceptable range and there was a large number of dead fishes found in the water body. The biological oxygen demand is the amount of dissolved oxygen needed by aerobic biological organisms in a water body to break down organic materials present in a given water sample at certain temperature over a specific time period, in the Bheema River the BOD was found to be $0.008 \mathrm{mg} / \mathrm{l}$ where as permissible range is $1 \mathrm{mg} / \mathrm{Lit}$ (WHO).

The calcium level in the Bheema River was found to be $19.23 \mathrm{mg} / \mathrm{l}$, which is lower than the WHO and BIS standards. According to WHO and BIS the permissible limit of Calcium is $72-200 \mathrm{mg} / \mathrm{l}$ and $250 \mathrm{mg} / \mathrm{l}$ which is less than the standard range of values prescribed by BIS and WHO. In the present investigation the chloride content of the Bheema river water (Saradagi dam) was found to be $126.22 \mathrm{mg} / \mathrm{l}$, as per WHO and BIS the permissible limit of chloride is $250 \mathrm{mg} /$ it indicates the chloride content is decreased. The determination of Hardness of Bheema river water sample was carried out. The total Hardness content of Bheema River was found to be $105 \mathrm{mg} / \mathrm{l}$ which is below the permissible range according to WHO and BIS standards. Therefore altered physicochemical parameters have affected the aquatic life. 


\section{III.1.2. Effect of water samples on the Haematological parameter of rats fed with water samples from Bheema River Day 1, Day 4, Day 7 and Control Group Treatment.}

Table No. 2

\begin{tabular}{|c|c|c|c|c|c|}
\hline Test & Control & One Day & Fourth day & Seventh day & Normal Range \\
\hline Haemoglobin & $13.2 \mathrm{gm} / \mathrm{dl}$ & $11.7 \mathrm{gm} / \mathrm{dl}$ & 11.5 & 13.2 & $11.0-17.0$ \\
\hline WBC Count & $10,200 /$ ul & $5,700 /$ ul & $6,500 /$ ul & $5,600 /$ ul & $4,000-10,000$ \\
\hline \multicolumn{6}{|l|}{ Differential count } \\
\hline Neutrophils & $20 \%$ & $90 \%$ & $92 \%$ & $95 \%$ & $27-55$ \\
\hline Lymphocytes & $79 \%$ & $09 \%$ & $07 \%$ & $04 \%$ & $36-55$ \\
\hline Eosinophils & $01 \%$ & $01 \%$ & $01 \%$ & $01 \%$ & $00-05$ \\
\hline Monocytes & $00 \%$ & $00 \%$ & $00 \%$ & $00 \%$ & 00.04 \\
\hline Basophils & $00 \%$ & $00 \%$ & $00 \%$ & $00 \%$ & $00-02$ \\
\hline \multicolumn{6}{|c|}{ (Method Vesmatic ESR Analyser) } \\
\hline Platelet Count & $5.50 \mathrm{Lakhs} \mathrm{cmm}$ & 3.19 Lakhs amm & $4.28 \mathrm{Lakhs} \mathrm{cmm}$ & $3.63 \mathrm{Lakhs} \mathrm{cmm}$ & $1,50,00-4,50,00$ \\
\hline R.B.C. Count & $7.6210 / u 1$ & $6.1610 / u 1$ & $6.4510 / u 1$ & $7.4210 /$ ul & $3.2-5.5$ \\
\hline P.C.V. & $47.2 \%$ & $37.1 \%$ & $40.9 \%$ & $49.2 \%$ & 37.47 \\
\hline M.C.V. & $61.9 \mathrm{fI}$ & $60.2 \mathrm{fI}$ & $63.4 \mathrm{fI}$ & $66.3 \mathrm{fI}$ & $82-92$ \\
\hline M.C.H. & $17.3 \mathrm{Pg}$ & $19 \mathrm{Pg}$ & $17.8 \mathrm{Pg}$ & $17.8 \mathrm{Pg}$ & $27-37$ \\
\hline M.C.R.C. & $28 \%$ & $31.5 \%$ & $28.1 \%$ & $26.8 \%$ & $32-36$ \\
\hline \multicolumn{6}{|c|}{ HEAMATOLOGI REPORT } \\
\hline Absolute Eosinophil Count & 180 Cellsul & 200 Cellul & 150 Cellsul & 200 Cells ul & $40-440$ \\
\hline Bleeding Time Min & $4 \mathrm{~min}, 0 \mathrm{sec}$ & $4 \mathrm{~min}, 0 \mathrm{sec}$ & $3 \mathrm{~min}, 30 \mathrm{sec}$ & $3 \mathrm{~min}, 45 \mathrm{sec}$ & $2-5$ \\
\hline Clotting Time Min & $7 \mathrm{~min}, 15 \mathrm{sec}$ & $6 \mathrm{~min}, 30 \mathrm{sec}$ & $6 \mathrm{~min}, 15 \mathrm{sec}$ & $6 \mathrm{~min}, 30 \mathrm{sec}$ & $2-9$ \\
\hline
\end{tabular}

\section{III.2.1. Effect on hematological parameters}

Blood is an important liquid connective tissue flow in body which performs the role of distribution of oxygen to various tissues and takes out carbon dioxide and maintains the health status of an organism. Any changes in the blood components can cause adverse effects on the body. Changes in blood components due to Bheema river water treatment has been evaluated in albino rats (Rattus norvegicus). The albino rats were treated with Bheema river water simultaneously for one day(1 day), four day (4 day) and seven day (7 day) along with control consisting of six rats in each group.

After feeding the Bheema river water to each group continuously for seven days we observed a large variation in the Haematological parameters in the albino rat. More variation in blood we found in the rats fed with the Bheema river water for one day (1 day) as compare to the other group, this is because the Bheema river water has shown the sudden effect on the body physiology of the rats which lead to the decrease in the immunity as well as decrease in the various other components of the blood.

The results revealed that the Hemoglobin content was significantly decreased compare to the Control group due to Bheema water treatment, Hemoglobin content in control rat found to be $13.3 \mathrm{gm} / \mathrm{dl}$ where as the Haemoglobin content in rats fed with Bheema river water for one day found to be $11.7 \mathrm{gm} / \mathrm{dl}$. The WBC Count also follows the same trend. Whereas the Neutrophils, Lymphocytes, and Eosinophils percentage were significantly increased compare to control group. The RBC count $(6.16 / \mathrm{ul})$ found to be decreased in first day water sample feeded group compare to control group (7.62/ul). The PCV, MCV, MCH, MCHC, value were significantly decreased when compare to the Control group. Further we observed that there was some variation in the Haematological parameters which shows a significant decreased in the Bleeding time and clotting time in the one day water feeded group compare to the control groups.

Further the values decreased as the duration of feeding increased. The above results clearly indicate that the water affects the haematological components may be due to pollution of water. Similar results were reported by the authors (Kanhiya Mahour and Prabhu N. Saxena journal of environmental science. September 2009.) 


\section{Conclusion}

By observing all the physicochemical and haematological parameters of Bheema river water at Saradagi dam, it can be concluded that the water quality has changed due to change in physico-chemical and the variation observed in BOD, DO, Phosphate, nitrate and changes in RBC, WBC, and hemoglobin content of blood indicates that the water is polluted and not fit for the drinking purpose.

\section{Acknowledgement}

The author Mr. Tathagat Waghmare thanks to Gulbarga University Gulbarga for providing laboratory to carry out the experiments.

\section{References}

[1]. Peterson NL: Sulfates in Drinking Water. Official Bulletin. NDWater Sewage Works Conf 18:6 $\pm 11,1951$,

[2]. B.I.S. Bureau of Indian Standards Drinking water specification, Ist revision, ISS 10500 (1991).

[3]. Agrawal I.C. and Srivastava H.C., pollution Survey of major drains discharge into river Ganga and Yamuna at Allahabad. Instn.Pub. Lic. Hlth. Engrs., TS III -48, (1984) American Public Health Association, Washington, D.C, 1992.

[4]. De, A. K., Environmental chemistry (6th edn.). New Delhi, India: New Age International Publishers (232) (2006).

[5]. Joshi, P.C and Singh, Analysis of certain physico-chemical parameters and planktons of fresh water hill stream at Nanda Devi biosphere reserve. Uttar Pradesh J. Zoo., 21: 177-179 (2001).

[6]. Moyle, J., Relationship between the chemistry and Minnesota surface waters and wild life management. J. Wild L. Marg, 20:303320 (1956).

[7]. Sastry, K. V. and Prathima Rathee, Physico-chemical and microbiological characteristics of water of village Kanneli (distt. Rohtak), Haryana. Proc. Acad. Biol., 7(1): 103-108 (1998)

[8]. Singh, A, Environmental chemistry (Ist edn.).Campus books international, Delhi (2006).

[9]. APHA, Standard method for the examination of water and waste water. APHA, AWWA, WPEC, 19th edition, New York,(1998).

[10]. Adekunle IM, Adetunji MT, Gbadebo AM, Banjoko OB (2007). Assessment of groundwater quality in a typical rural settlement in South West Nigeria. Int. J. Environ. Res. Public Health. 4(4): 307-318.

[11]. Akujieze CN, Coker SJ, Oteze GE (2003). Groundwater in Nigeria- a millennium experience- distribution, practice, problems and solution, Hydrogeol. J., 1: 259-274.

[12]. Adeyemi O, Oloyede OB, Oladiji AT. (2007a) Physicochemical and Microbial Characteristics of Leachate-contaminated Groundwater. Asian J Biochem.; 2(5): 343-348.

[13]. Akubugwo EI, Ude VC, Uhegbu FO, Ugbogu OC (2012). Physicochemical properties and heavy metal content of selected water sources in Ishiagu Ebonyi State-Nigeria. J. Bio. Environ. Sci., 2(2): 21-27.

[14]. Budavari, S.: An encyclopedia of chemicals, drugs and biologicals. White house station, N.J.: Merck and Co. Inc. 1003 (1996).

[15]. Bandyopadhyay et al. Int. J. Res. Chem. Environ. Vol. 2 Issue 1 January 2012 (160-165)

[16]. Bencko, V.; Geist, T.; Arbetova, D.; Dharmadikari, D.M. and Svandova, E. (1986): Biological monitoring of environmental pollution and human exposure to some trace elements. J. Hyg Epidemiol Microbiol Immunol, 30:(1) 1-10.

[17]. Caplat, C. (2001): Caractérisation géochimique des sédiments fins du littoral du Calvados (Baie de Seine)-Comparaison de matériaux portuaires contaminés à des matériaux non contaminés de la baie des Veys, Université de Caen, Thèse d' Université, Sciences de la Terre et de l' Univers 182.

[18]. Danadevi, K.; Rozati, R.; Banu, B.S. and Grover, P.(2004): Genotoxic evaluation of welders occupationally exposed to chromium and nickel using the Comet and micronucleus assays, 19:1, 35-41(7).

[19]. Dieter, M.P.; Jameson, C.W.; Tucker, A.N.; Luster, M.I.; French, J.E.; Hong, H.L. and Boorman, G.A.(1988): Evaluation of tissue disposition, myelopoietic, and immunologic responses in mice after longterm exposure to nickel sulfate in the drinking water. J.Toxicol Environ Health, 24:356-372.

[20]. Foulkes, E.C.: Biological Effects of Heavy Metals in Metal Carcinogenesis, Vol. II CRC Press, Florida USA (1990).

[21]. Grimsrund, T.K.; Berge, S.R.; Martinsen, J.I. and Andersen, A.(2003): Lung cancer incidence among Norwegian nickelrefineryworkers 1953-2000. J. Environ Monit, 5:190-197.

[22]. Hogson, E. (2004). Water and soil pollutants. In textbook of modern toxicology. 3th Eds. John Wiley and sons inc. New Jersey. USA. p. 42-57.

[23]. Hensen, J.C. and Deguchi, Y. (1996): Selenium and fertility in animals and man. A review Acta Vet. Scand, 37:19-30.

[24]. Ikem A, Osibanjo O, SridhaR MKC, Sobande A (2002). Evaluation of groundwater quality characteristics near two wastes sites in Ibadan and Lagos, Nigeria. Water, Air Soil., 140 (1-4): 307-333

[25]. Jagadeesan, G. and S. Sankarsami Pillai: Hepatoprotective effect of taurine against mercury induced toxicity in rat. J. Environ. Biol., 28 753-756 (2007). 